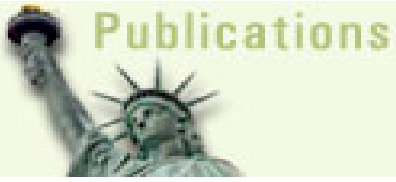

American Journal of Applied Sciences 5 (3): 234-241, 2008

ISSN 1546-9239

(C) 2008 Science Publications

\title{
Kinetic Study of the Effect of Benzoic Acid Derivatives on Copper Electrodeposition
}

\author{
Howaida M. El-Kashlan \\ Physics and Chemistry Department, Faculty of Education, Alexandria University, Alexandria, Egypt
}

\begin{abstract}
The effect of anodic oxygen bubbles on the rate of mass transfer in presence of benzoic acid, p-nitro, p-chloro and p-aminobenzoic acids were studied by measuring the limiting current of cathodic deposition of copper from acidified copper sulphate solution using lead anode. It is found that the rate of deposition decreases by adding organic substances. The rate of deposition depends on the type of inhibitor as well as its concentration. The ability of inhibitors to decrease the limiting current is as follows: p-nitrobenzoic $>$ p-chlorobenzoic $>$ benzoic $>$ p-aminobenzoic acid. The thermodynamic parameters prove that the reaction is diffusion controlled.
\end{abstract}

Keywords: kinetic, benzoic acid, electrodeposition

\section{INTRODUCTION}

In electrodeposition of metals usually an insoluble anode is used where oxygen evolution takes place. Anodic oxygen evolution could adversely affect the performance of the cell by increasing the ohmic drop ${ }^{[1-}$ ${ }^{3]}$ and disturbing the uniformity of current distribution [4-8]. On the other hand, anodic oxygen bubbles were found to enhance the rate of mass transfer at the cathode ${ }^{[9-12]}$ to the modest degree in vertical parallel electrode cell. In electrorefining, a soluble copper anode is used where the anodic reaction is copper dissolution instead of $\mathrm{O}_{2}$ evolution. Electrorefining and electrodeposition of copper are diffusion controlled processes whose rate depends on the physical properties of solution.

The aim of the present work is to study the effect of some organic substances as benzoic acid, p-nitro, pchloro and p-aminobenzoic acids on the rate of electrowining of copper at different temperatures.

\section{MATERIALS AND METHODS}

Experimental: Fig. 1 shows the cell and the circuit used in the present work. The cell consisted of a rectangular plastic container having the dimensions $5 \mathrm{x}$ $5 \times 10 \mathrm{~cm}$ with electrodes filling the whole cross section. The cathode was a rectangular sheet of $10 \mathrm{~cm}$ height and $5 \mathrm{~cm}$ width, the anode was a lead sheet of similar dimensions, and electrode separation was $5 \mathrm{~cm}$. In case of measuring the limiting current under natural convection, a copper anode was used instead of the lead anode.
The electrical circuit consisted of 6 volt D.C. power supply connected in series with the cell and a multirange ammeter. A voltammeter was connected in parallel with the cell to measure its voltage.

Polarization curves from which the limiting current was determined were constructed by increasing the current stepwise and measuring the steady state cathode potential against a copper reference electrode placed in the cup of a luggin tube whose tip was placed at about $1 \mathrm{~mm}$ from the cathode surface. To make sure that the decrease of $\mathrm{cu}^{++}$concentration during polarization was negligible in case of using lead anode, the limiting current was measured again potentiostatically using a fresh solution. The galvanostatic and the rapid potentiostatic methods gave almost the same limiting current. Before electrolysis the cathode and anode were isolated from their backs and sides with epoxy resin except at the contact with the feed wires. Six concentrations of $\mathrm{CuSO}_{4}$ were used namely, 0.1, 0.15, $0.2,0.25,0.3$ and $0.35 \mathrm{M}$. In all cases, $1.5 \mathrm{M} \mathrm{H}_{2} \mathrm{SO}_{4}$ was used as a supporting electrolyte. All chemicals were of A. R. grade, distilled water was used in preparing all solutions. Temperature was $25 \pm 1^{\circ} \mathrm{C}$. Each experiment was repeated twice using a fresh solution. $\mathrm{Cu}^{++}$ concentration was checked using iodometry ${ }^{[12]}$.

\section{RESULTS AND DISCUSSION}

Potentiodynamic cathodic polarization curves: Fig. 2 shows the cathodic polarization curve for copper electrodeposition from sulphate solution under the influence of adding different amounts of p-nitrobenzoic acid. It is obvious that in the organic free solution, the

Corresponding Author: Howaida El-Kashlan, Physics and Chemistry Department, Faculty of Education, Alexandria University, Alexnadria, Egypt 
current, first increases linearly, then tends to exhibit limiting current plateau with increasing the cathodic potential. It is generally accepted that electrodeposition of $\mathrm{Cu}^{++}$ions takes place through two steps:
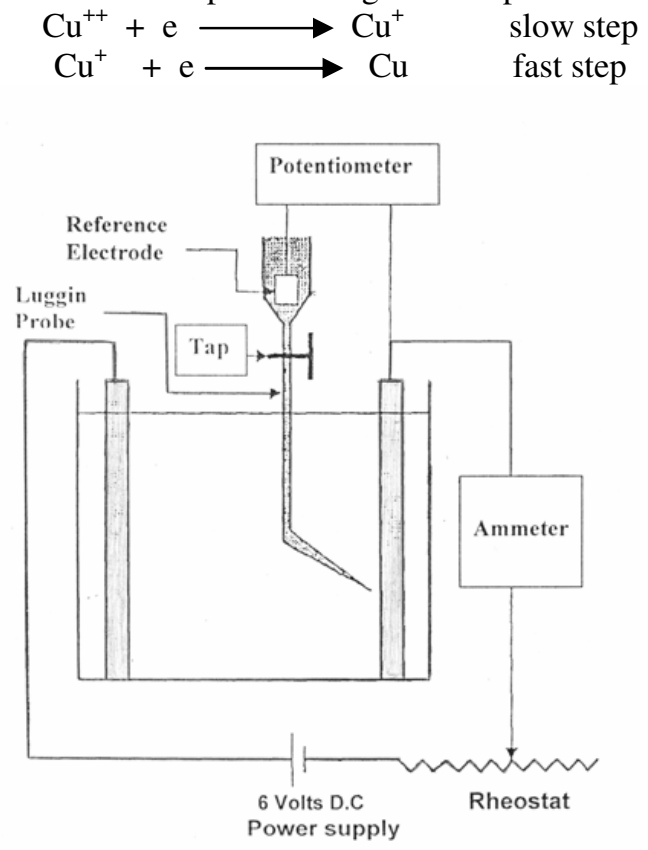

Fig. 1: The electrolytic cell and the electrical circuit showing the position of the two parallel vertical plates and the reference electrode

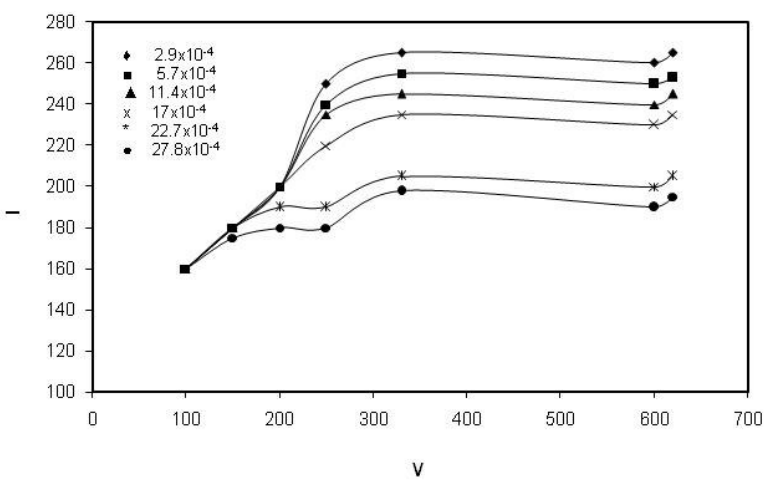

Fig. 2: The relation between I \& V in presence of nitrobenzoic acid at $303^{\circ} \mathrm{K}$ and $0.15 \mathrm{M} \mathrm{CuSO}_{4}$

It was assumed that the first step in this process occurred slowly and the rate was controlled by equilibrium between $\mathrm{Cu}^{++}$and $\mathrm{Cu}^{+}$at the electrode surface. However, addition of organic substances to the sulphate solution increases the cathodic polarization and decreases the value of limiting current density. The observed changes in the cathodic polarization in the presence of organic compound suggest that it must be acting as inhibitor, which is confirmed by the observation that at any given over potential, the current density for copper deposition from solutions containing organic compound is lower than that found for the corresponding organic free solution. This inhibition of the organic compound on the copper electrodepoition reaction may be due to the adsorption of organic compound on the cathode surface and/or the complexation of $\mathrm{Cu}^{++}$with the organic compound.

As the organic concentration in the bath increased, most of the $\mathrm{Cu}^{++}$ions become complexed. For given concentration, the rate of transport of copper organic complex is lower than for $\mathrm{Cu}^{++}$ion because of the lower value of the diffusion coefficient of a complexed ion ${ }^{[13]}$. Therefore, the current plateau decreases with increasing organic concentration as predicted in figure (2) due to a lowering of the uncomplexed $\mathrm{Cu}^{++}$ions.

Table 1: limiting current of different organic compounds (mA) at different temperatures

\begin{tabular}{cccccc}
\hline $\begin{array}{c}\text { Organic } \\
\text { compounds }\end{array}$ & $\begin{array}{c}\mathrm{Cx} 10^{-4} \\
\mathrm{~mol}^{-1}\end{array}$ & $298^{\circ} \mathrm{K}$ & $303^{\circ} \mathrm{K}$ & $308^{\circ} \mathrm{K}$ & $313^{\circ} \mathrm{K}$ \\
\hline & 0 & 210 & 270 & 315 & 345 \\
p- & 2.9 & 200 & 260 & 295 & 310 \\
nitrobenzoic & 11.4 & 190 & 240 & 270 & 285 \\
& 17 & 180 & 230 & 235 & 280 \\
& 22.7 & 175 & 200 & 225 & 245 \\
& 27.8 & 170 & 190 & 215 & 225 \\
p-chloro & 0.0 & 260 & 270 & 315 & 345 \\
benzoic & 2.5 & 255 & 265 & 290 & 325 \\
& 10.0 & 205 & 260 & 280 & 280 \\
& 15.0 & 190 & 240 & 250 & 240 \\
& 20.0 & 185 & 230 & 240 & 260 \\
p- & 25 & 180 & 210 & 230 & 255 \\
& 0.0 & 260 & 270 & 315 & 345 \\
aminobenzoic & 11.29 & 190 & 265 & 305 & 325 \\
& 22.48 & 180 & 260 & 295 & 310 \\
& 64.53 & 175 & 255 & 285 & 295 \\
& 87.35 & 170 & 250 & 270 & 280 \\
& 108 & 165 & 245 & 255 & 265 \\
benzoic acid & 34.39 & 190 & 230 & 235 & 245 \\
& 51.10 & 180 & 230 & 235 & 280 \\
& 67.47 & 175 & 200 & 225 & 270 \\
& 83.54 & 170 & 190 & 215 & 225 \\
\hline
\end{tabular}

Values of limiting current for all solutions at different temperatures using lead anode are given in table (1). Noticeably, the limiting current decreases with increasing the organic additives concentration and 
increases with temperature. The mass transfer coefficient was calculated from equation (1)

$$
\mathrm{k}=\frac{\mathrm{I}}{\mathrm{ZFC}_{\mathrm{o}}}
$$

$\mathrm{I}=$ limiting current density, $\mathrm{z}$ valency, $\mathrm{F}$ Faraday constant, $\mathrm{C}_{0}$ concentration of $\mathrm{CuSO}_{4}$.

From table (2) we notice that velocity (V) and mass transfer coefficient $(\mathrm{k})$ for all organic compounds are decreased with increase of the mole fraction of the organic compounds.

Fig. 3 shows that when lead anode was used, in absence of the organic substance, the blank data fits well into equation which agrees with the earlier finding derived from the hydrodynamic boundary layer theory (12).

$$
\mathrm{J}=1.096(\operatorname{Re} . \mathrm{Fr})-0.176
$$

The gas discharge velocity $\mathrm{V}$ used in calculating $\mathrm{J}$, Re and Fr was calculated from equation (3) Ahmed et al ${ }^{[12]}$ predicted that $\left(\mathrm{k} \alpha \mathrm{V}^{0.18}\right)$

$$
\mathrm{V}=(\mathrm{IRT}) /(4 \mathrm{PF})
$$

In presence of organic substance, the following relation was obtained:

$$
\mathrm{k} \alpha(\mathrm{V})^{\mathrm{b}}
$$

\begin{tabular}{|c|c|c|c|c|}
\hline $\begin{array}{l}\text { Ogranic } \\
\text { compound }\end{array}$ & $\begin{array}{l}\mathrm{Cx} 10^{-4} \\
\mathrm{~mol} \mathrm{l}^{-1}\end{array}$ & $\begin{array}{c}\mathrm{I}_{1}(\mathrm{~mA}) \\
\text { Organic } \\
\text { comp. }\end{array}$ & $\begin{array}{l}\text { V.10 } \\
\text { cm.s }\end{array}$ & $\begin{array}{l}\mathrm{k} \cdot 10^{6} \\
\mathrm{~cm} \cdot \mathrm{s}^{-1}\end{array}$ \\
\hline & 2.9 & 260 & 1.67 & 8.98 \\
\hline & 5.7 & 260 & 1.67 & 8.98 \\
\hline & 11.4 & 250 & 1.61 & 8.41 \\
\hline \multirow{5}{*}{ nitrobenzoic } & 17 & 230 & 1.48 & 7.95 \\
\hline & 22.7 & 220 & 1.42 & 7.6 \\
\hline & 27.8 & 215 & 1.38 & 7.43 \\
\hline & 2.5 & 265 & 1.71 & 9.11 \\
\hline & 5 & 260 & 1.67 & 8.95 \\
\hline p-chloro & 10 & 250 & 1.61 & 8.64 \\
\hline \multirow[t]{5}{*}{ benzoic } & 15 & 290 & 1.51 & 8.12 \\
\hline & 20 & 230 & 1.48 & 7.91 \\
\hline & 25 & 225 & 1.35 & 7.28 \\
\hline & 5.72 & 260 & 1.67 & 8.98 \\
\hline & 17.37 & 250 & 1.61 & 8.64 \\
\hline \multirow{6}{*}{$\underline{\text { Benzoic }}$} & 34.39 & 240 & 1.55 & 8.29 \\
\hline & 51.10 & 230 & 1.48 & 7.95 \\
\hline & 67.47 & 200 & 1.29 & 6.91 \\
\hline & 83.54 & 190 & 1.23 & 6.56 \\
\hline & 11.29 & 265 & 1.71 & 9.16 \\
\hline & 22.48 & 260 & 1.67 & 8.95 \\
\hline \multirow{4}{*}{$\begin{array}{c}\mathrm{p}- \\
\text { aminobenzoic }\end{array}$} & 44.53 & 255 & 1.64 & 8.81 \\
\hline & 66.15 & 250 & 1.61 & 8.64 \\
\hline & 87.35 & 245 & 1.58 & 8.46 \\
\hline & 108 & 230 & 1.48 & 7.95 \\
\hline
\end{tabular}

where " $b$ " is constant depending on organic substances.

Table 2: The variation of $\mathrm{k}$ and $\mathrm{v}$ for different organic
Plot $\log \mathrm{k}$ against $\log \mathrm{V}$ for different organic compounds gave a good straight line as shown in figure (4) and table (2). The values of the slope (b) were found to be constant for all studied additives and its values approximately equal one as shown in table 3, which indicates that the discharge velocity of oxygen gas is affected by the presence of additive compounds to same extent as the mass transfer coefficient does.

Table 3: Values of (b) for different organic substances using lead anode.

\begin{tabular}{cc}
\hline Organic substance & $\mathrm{b}$ \\
\hline p-nitrobenzoic acid & 1.06 \\
p-chlorobenzoic acid & 1.077 \\
benzoic acid & 1.05 \\
p-aminobenzoic acid & 1 \\
\hline
\end{tabular}

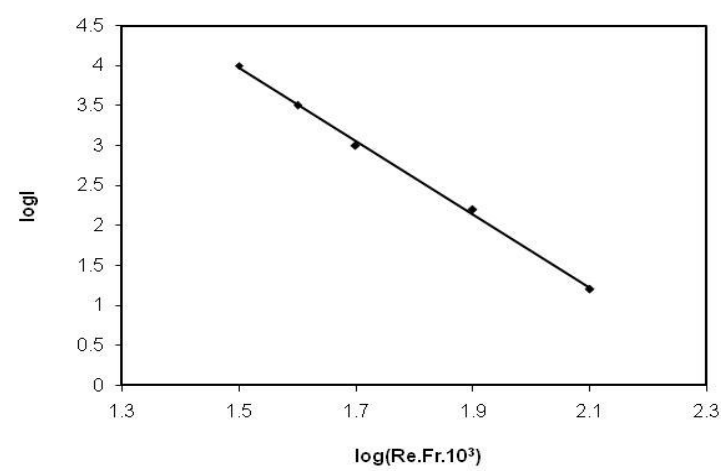

Fig. 3: Overall mass transfer correlation at vertical plates

Effect of organic substance on the limiting current: The limiting current in absence of organic compound $\left(\mathrm{I}_{\mathrm{b}}\right)$ and in presence of organic compound $\left(\mathrm{I}_{\text {org }}\right)$, is related to the percentage of inhibition by the equation:

$$
\text { \%inhibition }=\left[\mathrm{I}_{\mathrm{b}}-\mathrm{I}_{\text {org }}\right] / \mathrm{I}_{\mathrm{b}} \mathrm{X} 100
$$

Fig. 5 and table 4 show that the percentage inhibition caused by organic compounds ranges from $1.85 \%$ to $29.63 \%$.

The percentage inhibition was found to be dependent on types of inhibitor and its concentration. The percentage inhibition increases as concentration increases. The order of inhibition is as follows: pnitrobenzoic $>$ p-chloro $>$ benzoic $>$ p-aminobenzoic acid.

The obtained results show that the presence of organic compound has an inhibiting effect on the kinetics of the copper discharge process, pointed out by the decrease of the exchange current intensity. The inhibition enhancing due to increasing the organic compound concentration could be related to the strong adsorption of organic compound constituents on the 
copper electrode surface, which is in agreement with the decay of the current intensity observed on the polarization curves.

The presence of organic compound changes the mechanism of the copper electrodeposition as it can be seen from the decreasing of the cathodic transfer coefficient. A possible explanation for this fact is the increasing role of an additional reaction that produces the same mechanical species $\left(\mathrm{Cu}^{+}\right)$as those involved in the rate determining reaction ${ }^{[14]}$.

Table 4: The effect of concentration of organic compounds and the \% inhibition of the limiting current at $303^{\circ} \mathrm{K}$

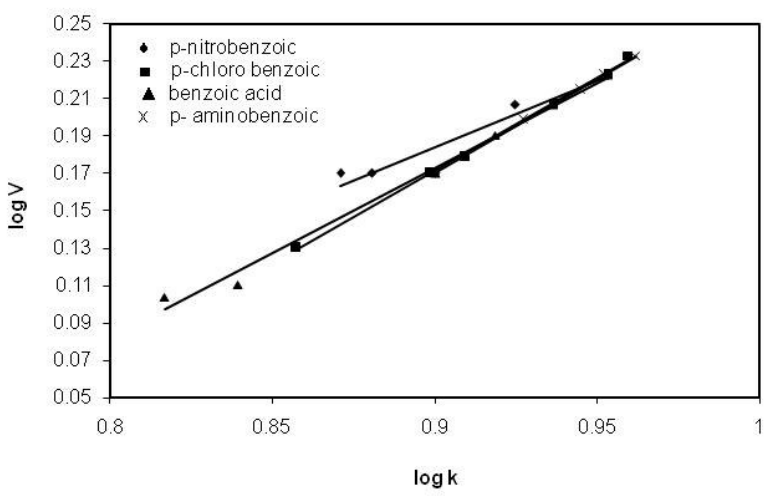

Fig. 4: The relation between $\log \mathrm{k}$ and $\log \mathrm{V}$ for different organic compounds at $303^{\circ} \mathrm{K}$

\begin{tabular}{|c|c|c|c|c|}
\hline $\begin{array}{l}\text { Ogranic } \\
\text { compound }\end{array}$ & $\begin{array}{l}\mathrm{Cx} 10^{-4} \\
\mathrm{~mol} \mathrm{l}^{-1}\end{array}$ & $\begin{array}{c}\mathrm{I}_{\mathrm{l}}(\mathrm{mA}) \\
\text { blank }\end{array}$ & $\begin{array}{c}\mathrm{I}_{1}(\mathrm{~mA}) \\
\text { Organic } \\
\text { comp. }\end{array}$ & $\begin{array}{c}\% \\
\text { inhibition }\end{array}$ \\
\hline \multirow{6}{*}{ p-nitrobenzoic } & 2.9 & \multirow{6}{*}{270} & 260 & 3.704 \\
\hline & 5.7 & & 260 & 3.704 \\
\hline & 11.4 & & 250 & 7.407 \\
\hline & 17 & & 230 & 14.82 \\
\hline & 22.7 & & 220 & 18.52 \\
\hline & 27.8 & & 215 & 20.37 \\
\hline \multirow{6}{*}{$\begin{array}{l}\text { p-chloro } \\
\text { benzoic }\end{array}$} & 2.5 & \multirow{6}{*}{270} & 265 & 1.852 \\
\hline & 5 & & 260 & 3.704 \\
\hline & 10 & & 250 & 7.407 \\
\hline & 15 & & 240 & 11.11 \\
\hline & 20 & & 230 & 14.82 \\
\hline & 25 & & 225 & 16.67 \\
\hline \multirow{7}{*}{$\underline{\text { Benzoic }}$} & 5.72 & \multirow{6}{*}{270} & 260 & 3.704 \\
\hline & 17.37 & & 250 & 7.407 \\
\hline & 34.39 & & 240 & 11.11 \\
\hline & 51.10 & & 230 & 14.83 \\
\hline & 67.47 & & 200 & 25.93 \\
\hline & 83.54 & & 190 & 29.63 \\
\hline & 11.29 & \multirow{6}{*}{270} & 265 & 1.852 \\
\hline \multirow{5}{*}{ 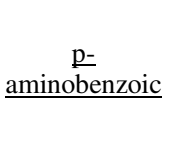 } & 22.48 & & 260 & 3.704 \\
\hline & 44.53 & & 255 & 5.504 \\
\hline & 66.15 & & 250 & 7.407 \\
\hline & 87.35 & & 245 & 18.52 \\
\hline & 108 & & 230 & 20.39 \\
\hline
\end{tabular}

Adsorption isotherm: It is generally assumed that the adsorption of the inhibitor at the metal solution interface is the first step in the action mechanism of inhibitors in aggressive acid media. Four types of adsorption may take place in the inhibiting phenomena involving organic molecules at the (meta-solution) interface, namely:

1. Electrostatic attraction between charged molecules and the charged metal.

2. Interaction of uncharged electron pairs in the molecules with the metal.

3. Interaction of electron with metal

4. A combination of the above ${ }^{[15]}$.

Chemisorption involves sharing or charge transfer from the inhibitor molecule to the surface in order to form coordinate bond. In fact, electron transfer is typical for transition metals having vacant low energy electron orbital.

Adsorption isotherms are very important in determining the mechanism of organo-electrochemical reactions. The most frequently used isotherms are those of Langmuir, Frumkin, Parsons, Temkin, FloryHuggins and Bockris-swinkels ${ }^{[16-19]}$. All these isotherms are of the general form:

$$
\mathrm{f}(\theta, \mathrm{x}) \exp (-\alpha \theta)=\mathrm{KC}
$$

where $f(\theta, x)$ is the configurational factor that depends essentially on the physical model and assumptions underlying the derivation of the isotherm. Inhibitor adsorption characteristics were estimated by using the Langmuir isotherm ${ }^{[20,21]}$, equation (6):

$$
\mathrm{KC}=(\theta / 1-\theta)
$$

Where $\mathrm{K}$ is the equilibrium constant of adsorption process, $\mathrm{C}$ is the concentration and $\theta$ is the surface coverage.

The degree of surface coverage $(\theta)$ at constant temperature was determined from ${ }^{[22]}$ :

$$
\theta=\left(\mathrm{I}_{\mathrm{b}}-\mathrm{I}_{\text {org }}\right) / \mathrm{I}_{\mathrm{b}}
$$

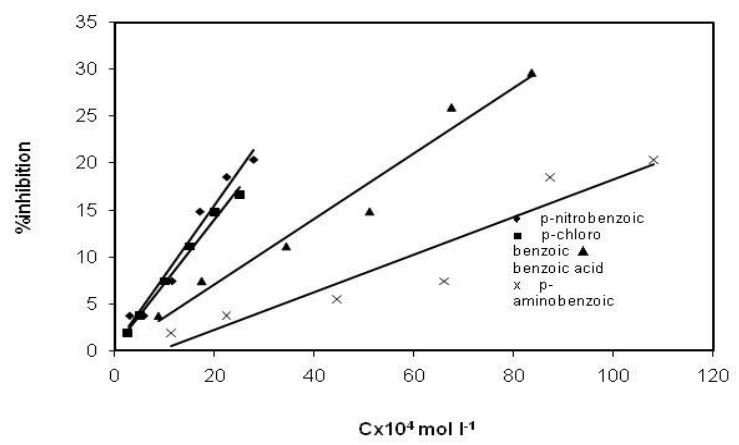

Fig 5: The relation between percentage inhibition and concentrtaion for all organic substances at $303^{\circ} \mathrm{K}$ 


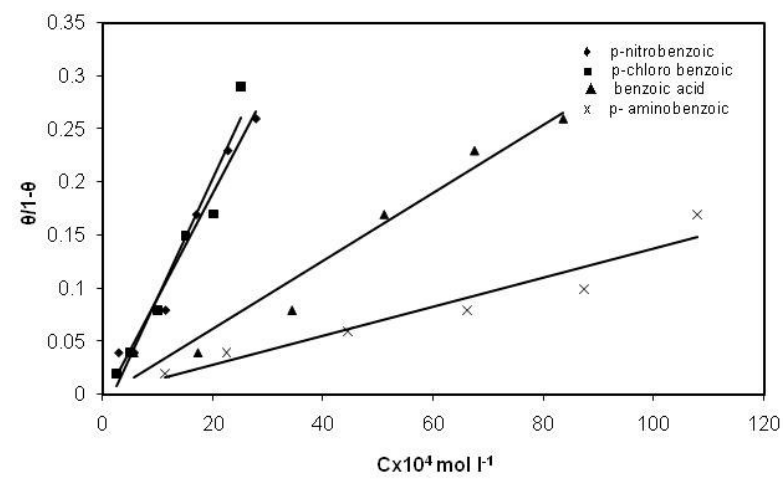

Fig. 6: The relation between $\theta / 1-\theta$ and $\mathrm{C}$ for different organic compounds at $303^{\circ} \mathrm{K}$

Table 5 gives the data between $(\theta / 1-\theta)$ vs $C$ for all organic substances of the surface coverage $\theta$ with concentration variation at $303 \mathrm{~K}$. From equation (6) a plot of $(\theta / 1-\theta)$ vs. C should yield straight line, thus figure (6) shows straight line indicating that all the inhibitors verify Langmuir adsorption isotherm.

Figure (7) shows the Flory-Huggins adsorption isotherm plotted as $\log \theta / \mathrm{C}$ vs. $\log (1-\theta)$ for $\mathrm{CuSO}_{4} / \mathrm{H}_{2} \mathrm{SO}_{4}$ organic compounds at $303 \mathrm{~K}$ yields a straight line with slope $\mathrm{x}$ and intercept log (xk). Table (6) shows the values of $\mathrm{x}$ and $\mathrm{k}$, the experimental data fits Flory-Huggins adsorption isotherm which represented by:

$\log \theta / C=\log (x K)+x \log (1-\theta)$

Here $\mathrm{x}$ is the number of water molecules replaced by one molecule of the inhibitor. It is clear that the surface coverage data are useful for discussing adsorption characteristics. The adsorption of inhibitors at metal solution interface may be due to the formation of either electrostatic or covalent bonding between the adsorbents and the metal surface atoms ${ }^{[23,24]}$.

The free energy of adsorption $\left(\Delta \mathrm{G}_{\mathrm{ads}}\right)$ at different concentrations was calculated from equation:

$$
\Delta \mathrm{G}_{\mathrm{ads} .}=-\mathrm{RT} \ln (55.5 \mathrm{~K})
$$

The values of $\Delta \mathrm{G}_{\mathrm{ads}}$ are given in table (6). In all cases, the $\Delta \mathrm{G}_{\mathrm{ads}}$. values are negative and lie in the range of 12.652 to $-22.019 \mathrm{kj} / \mathrm{mol}$. The most efficient inhibitors show the most negative $\Delta \mathrm{G}_{\mathrm{ads}}$. value. This suggests that they are strongly adsorbed on the metal surface. The negative values of $\Delta \mathrm{G}_{\mathrm{ads}}$. indicate the spontaneous adsorption of the inhibitor. This is usually characteristic of strong interaction with metal surface. It is found that the $\Delta G_{\text {ads. }}$ values are more positive than $-40 \mathrm{~kJ} / \mathrm{mol}$ indicating that inhibitors are physically adsorbed on the metal surface. Similar results have also been reported by Talati et. al ${ }^{[25]}$.

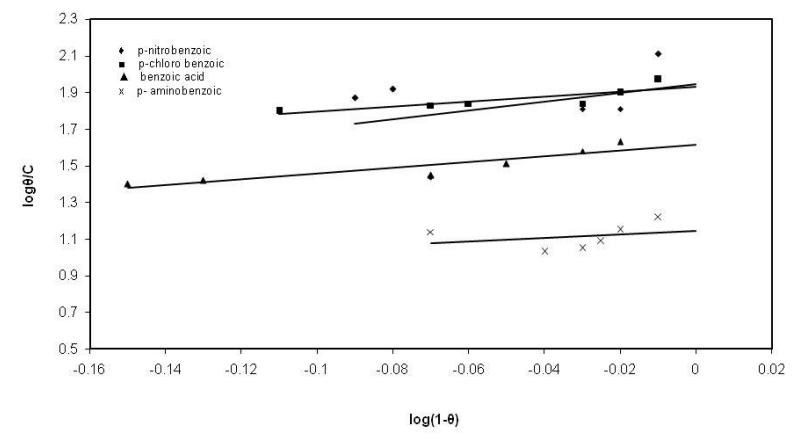

Fig. 7: The relation between $\log \theta / \mathrm{C}$ and $\log 1-\theta$ for different organic compounds at $303^{\circ} \mathrm{K}$

Effect of organic additives: It is known that many additives are usually capable of adsorption on the cathodic substrate and even might trap in the deposit. Some additives also increase the deposition overpotential. This may be due to either the need for the electron transfer to occur through the adsorbed layer or to a complex formation at the electrode surface. A complexation of the metal cation in solution is also proposed. In many cases the use of additives is till done in an empirical way. Indeed, the number of these organic or non organic substances is very large. Moreover, their action could be different in function of the substrate, the ion to reduce and the electrolytic conditions. For example, additive re-orientation on the electrode surface has been observed ${ }^{[26,27]}$ depending on the surface coverage or as a function of $\mathrm{pH}$. A synergetic effect, often noticed when several additives are added to the solution even confuses the issue.

An explanation for the decrease of the rate of deposit may be due to that water molecules bounded by hydrogen bond to an acid are less nucleophilic than water molecules bounded by a hydrogen bond with each other. Also the results obtained in case of acid are interpreted on the basis that the metal surface is preferentially covered by acid molecules ${ }^{[28]}$.

Acids increase the local solution viscosity at cathode surface with a consequent decrease in the diffusivity of copper ion and the decrease in the rate of deposition with increasing the concentration of acids, which is attributed to acid molecules slower the natural convection flow arising from the density difference between bulk solution and solution at the electrode surface due to the attraction force between the cathode surface and coo $^{-}$group of the acid.

Rate of deposition and the limiting current is observed to decrease in the presence of electrolyte or acids probably due to the decrease of the conductivity of 
solution mixture in the presence of acids. The limiting current is found to be lower in the presence of the acids added to solution than in absence of acids. The decrease of rate will depend on the acids composition and its structures, the protolytic action and oxygen solubility. It is found that the rate of electrodeposition increases in the following order:

p-nitrobenzoic $>$ p-chloro $>$ benzoic $>$ p-aminobenzoic acid.

This is explained on the basis that nitro group is electron withdrawing group which make the $-\mathrm{COOH}$ group to be more ionized i.e. acid reacts with copper ion easily. The equilibrium will be shifted to right and less copper deposited.

$$
\begin{gathered}
\mathrm{Cu}====\mathrm{Cu}^{++}+2 \mathrm{e}^{-} \\
2-\mathrm{COOH}+\mathrm{Cu}^{++}=====-(\mathrm{COO})_{2} \mathrm{Cu}
\end{gathered}
$$

The $-\mathrm{I}$ effect of nitro group is more than $\mathrm{Cl}^{-}$ion. This explains the rate of deposition of 4-nitro is more than 4chlorobenzoic. For 4-aminobenzoic, amino group is electron releasing group which has $+\mathrm{I}$ effect, so the dissociation of $\mathrm{COOH}$ group will be less than in case of benzoic acid.

It is found that the rate of deposition decrease by increasing the concentration of acids. This is explained on the basis that, this substance adsorbed on the surface of cathode led to an inhibition effect.

Effect of temperature: The electrodeposition of copper in presence of different inhibitors was studied by measuring the limiting current over the temperature range from $\left(298-313^{\circ} \mathrm{C}\right)$. Table (1) shows the limiting current obtained in presence of organic additives at different temperatures. The results indicate that the rate of electrodeposition increases with increasing the temperature. The above behaviour is indicative of the occurrence of the electrodeposition through physical adsorption of additive on the metal surface. Desorption is aided by increasing the reaction temperature.

The value of $I_{1}$ obtained at different temperatures permits the calculation of activation energy $E_{a}$ according to Arrhenius equation:

$$
\log \mathrm{I}_{1}=-\mathrm{E}_{\mathrm{a}} / 2.303 \mathrm{RT}+\log \mathrm{A}
$$

The plot of $I_{1}$ against $1 / T$ gave a straight line where $A$ is Arrhenius constant, $\mathrm{R}$ is the gas constant and $\mathrm{T}$ is the absolute temperature. The slope of which is proportional to $E_{a}$. The activation energy of the process is an important parameter for determining the rate controlling step. If the rate controlling step is the diffusion of the species in the boundary layer then $E_{a}$ is generally $\leq 28 \mathrm{~kJ} / \mathrm{mol}$, while $\mathrm{E}_{\mathrm{a}}$ values usually $>43$ $\mathrm{kJ} / \mathrm{mol}$ when adsorption of the species on the metal surface and subsequent chemical reaction take place.

Table 7 shows that the values of $E_{a}$ are lower than 43 $\mathrm{kj} / \mathrm{mol}$; characterizing that diffusion processes are controlling the electrodeposition reaction.

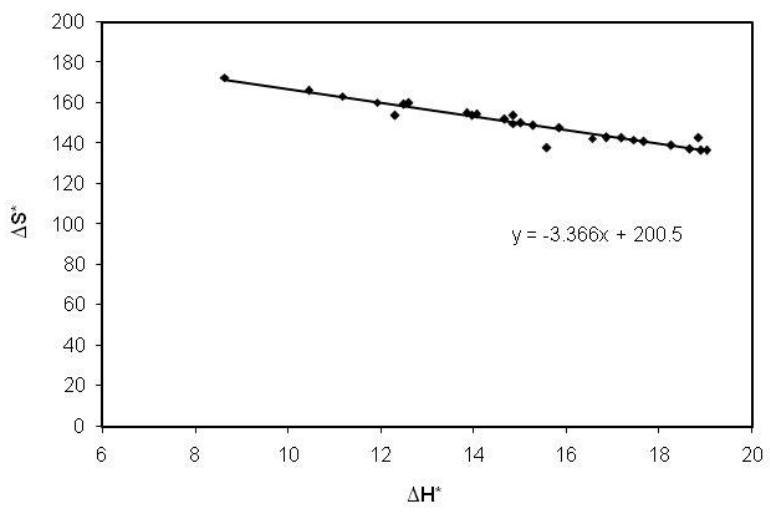

Fig. 8: The relation between $\Delta \mathrm{S}^{*}$ and $\Delta \mathrm{H}^{*}$ for all organic compounds

Thermodynamic treatment of the reaction: The values of the enthalpy of activation $\Delta \mathrm{H}^{*}$, entropy of activation $\Delta \mathrm{S}^{*}$ and free energy of activation $\Delta \mathrm{G}^{*}$ can be obtained by using equations:

$$
\begin{aligned}
\Delta \mathrm{H}^{*} & =\mathrm{E}_{\mathrm{a}}-\mathrm{RT} \\
\frac{\Delta S^{*}}{R} & =\ln (A)-\ln \left(\frac{B T e}{h}\right) \\
\Delta \mathrm{G}^{*} & =\Delta \mathrm{H}^{*}-\mathrm{T} \Delta \mathrm{S}^{*}
\end{aligned}
$$

Table (7) shows that the entropy $\Delta \mathrm{S}^{*}$ possesses negative values, indicating a highly ordered organic species in the solution under investigation. From the table (7) and Fig. (8), it is also noticed that the weak

\begin{tabular}{|c|c|c|c|c|c|}
\hline \multirow[b]{2}{*}{ Organic compounds } & \multicolumn{2}{|c|}{ Langmuir } & \multicolumn{3}{|c|}{ Flury-Huggins } \\
\hline & $\mathrm{k}$ & $\underset{\mathrm{kJ}^{2} \cdot \mathrm{mol}^{-1}}{\Delta \mathrm{G}_{\text {ads. }}}$ & $\mathrm{x}$ & $\mathrm{k}$ & $\underset{\mathrm{kJ} \cdot \mathrm{mol}^{-1}}{\Delta \mathrm{G}_{\text {ads. }}}$ \\
\hline p-nitrobenzoic & 97.887 & 21.309 & 2.809 & 81.194 & 19.655 \\
\hline p-chloro benzoic & 83.496 & 20.914 & 0.5848 & 130.46 & 22.019 \\
\hline benzoic acid & 51.512 & 19.714 & 0.5416 & 81.194 & 20.844 \\
\hline p- aminobenzoic & 14.117 & 16.501 & 6.419 & 2.975 & 12.652 \\
\hline
\end{tabular}
dependence of $\Delta \mathrm{G}^{*}$ on the composition of the organic additives can be attributed largely to the general linear compensation between $\Delta \mathrm{H}^{*}$ and $\Delta \mathrm{S}^{*}$ for the given temperature.

Table 6: values of $\mathrm{k}, \mathrm{x}$ and $\Delta \mathrm{G}_{\text {ads. }}$ of organic compound in Langmuir and Flury-Huggins 
Am. J. Applied Sci., 5 (3): 234-241, 2008

Table 5: The data of the adsorption isotherm at 303k

\begin{tabular}{|c|c|c|c|c|c|c|}
\hline $\mathrm{Cx} 10^{-4} \mathrm{~mol} \mathrm{l}^{-1}$ & $\mathrm{I}_{1}$ & $\theta$ & $1-\theta$ & $\theta / 1-\theta$ & $\log 1-\theta$ & $\log \theta / \mathrm{c}$ \\
\hline \multicolumn{7}{|l|}{ p-nitrobenzoic } \\
\hline 2.9 & 260 & 0.04 & 0.96 & 0.04 & -0.01 & 2.11 \\
\hline 5.7 & 260 & 0.04 & 0.96 & 0.04 & -0.02 & 1.81 \\
\hline 11.4 & 250 & 0.07 & 0.93 & 0.08 & -0.03 & 1.81 \\
\hline 17 & 230 & 0.15 & 0.85 & 0.17 & -0.07 & 1.44 \\
\hline 22.7 & 220 & 0.19 & 0.81 & 0.23 & -0.08 & 1.92 \\
\hline 27.8 & 215 & 0.2 & 0.80 & 0.26 & -0.09 & 1.87 \\
\hline \multicolumn{7}{|l|}{ p-chloro benzoic } \\
\hline 2.5 & 265 & 0.02 & 0.95 & 0.02 & -0.01 & 1.97 \\
\hline 5 & 260 & 0.04 & 0.96 & 0.04 & -0.02 & 1.90 \\
\hline 10 & 250 & 0.07 & 0.93 & 0.08 & -0.03 & 1.84 \\
\hline 15 & 235 & 0.13 & 0.87 & 0.15 & -0.06 & 1.84 \\
\hline 20 & 230 & 0.15 & 0.85 & 0.17 & -0.07 & 1.83 \\
\hline 25 & 210 & 0.22 & 0.79 & 0.29 & -0.11 & 1.8 \\
\hline \multicolumn{7}{|l|}{ Benzoic } \\
\hline 5.72 & 260 & 0.04 & 0.96 & 0.04 & -0.02 & 1.63 \\
\hline 17.37 & 260 & 0.07 & 0.93 & 0.04 & -0.03 & 1.58 \\
\hline 34.39 & 241 & 0.11 & 0.89 & 0.08 & -0.05 & 1.51 \\
\hline 51.10 & 230 & 0.15 & 0.85 & 0.17 & -0.07 & 1.45 \\
\hline 67.47 & 200 & 0.26 & 0.84 & 0.23 & -0.13 & 1.42 \\
\hline 83.54 & 190 & 0.29 & 0.81 & 0.26 & -0.15 & 1.40 \\
\hline \multicolumn{7}{|l|}{ p-aminobenzoic } \\
\hline 11.29 & 265 & 0.02 & 0.98 & 0.02 & -0.01 & 1.22 \\
\hline 22.48 & 260 & 0.04 & 0.96 & 0.04 & -0.02 & 1.15 \\
\hline 44.53 & 255 & 0.06 & 0.94 & 0.06 & -0.025 & 1.09 \\
\hline 66.15 & 250 & 0.07 & 0.93 & 0.08 & -0.03 & 1.05 \\
\hline 87.35 & 245 & 0.09 & 0.91 & 0.10 & -0.04 & 1.03 \\
\hline 108 & 230 & 0.15 & 0.85 & 0.17 & -0.07 & 1.14 \\
\hline
\end{tabular}

Table 7: thermodynamic parameters for electrodeposition of copper in presence of organic substances

\begin{tabular}{|c|c|c|c|c|c|}
\hline Ogranic compound & $\mathrm{Cx} 10^{-4} \mathrm{~mol} \mathrm{l}^{-1}$ & $\begin{array}{c}\mathrm{E}_{\mathrm{a}} \\
\mathrm{kJ} \cdot \mathrm{mol}^{-1}\end{array}$ & $\begin{array}{c}\Delta \mathrm{H}^{*} \\
\mathrm{~kJ} \cdot \mathrm{mol}^{-1}\end{array}$ & $\begin{array}{c}\Delta \mathrm{S}^{*} \\
\text { J.mol.k } \\
\end{array}$ & $\begin{array}{c}\Delta \mathrm{G}^{*} \\
\mathrm{~kJ} \cdot \mathrm{mol}^{-1}\end{array}$ \\
\hline \multirow{8}{*}{ p-nitrobenzoic } & 0.0 & 21.38 & 18.9 & 136.5 & 59.61 \\
\hline & 2.9 & 20.15 & 17.67 & 140.8 & 59.65 \\
\hline & 5.7 & 20.0 & 17.45 & 141.8 & 59.73 \\
\hline & 11.4 & 18.0 & 15.29 & 149.1 & 59.75 \\
\hline & 17 & 16.38 & 13.96 & 154 & 59.89 \\
\hline & 22.7 & 15.08 & 12.60 & 159.9 & 59.96 \\
\hline & 27.8 & 15.0 & 12.50 & 159.6 & 60.06 \\
\hline & 0.00 & 19.33 & 16.55 & 142.52 & 59.44 \\
\hline \multirow{6}{*}{ p-chloro benzoic } & 2.5 & 21.05 & 15.58 & 137.83 & 59.64 \\
\hline & 5 & 19.33 & 16.85 & 143.83 & 59.74 \\
\hline & 10 & 17.5 & 15.01 & 150.30 & 59.82 \\
\hline & 15 & 18.3 & 15.85 & 147.9 & 59.95 \\
\hline & 20 & 17.1 & 14.66 & 152.2 & 60.04 \\
\hline & 25 & 16.33 & 13.85 & 155.1 & 60.07 \\
\hline \multirow{8}{*}{$\underline{\text { Benzoic }}$} & 0.00 & 19.33 & 16.85 & 142.83 & 59.44 \\
\hline & 5.72 & 17.33 & 14.85 & 149.96 & 59.56 \\
\hline & 17.37 & 14.78 & 12.3 & 153.8 & 59.65 \\
\hline & 34.39 & 14.4 & 11.92 & 160.4 & 59.75 \\
\hline & 51.10 & 13.65 & 11.17 & 163.4 & 58.88 \\
\hline & 67.47 & 12.92 & 10.45 & 166 & 60.03 \\
\hline & 83.54 & 11.11 & 8.63 & 172.71 & 60.12 \\
\hline & 0.00 & 19.33 & 18.85 & 142.83 & 54.44 \\
\hline \multirow{6}{*}{ p-aminobenzoic } & 11.29 & 21.14 & 18.66 & 137.3 & 59.6 \\
\hline & 22.48 & 21.5 & 19.02 & 136.47 & 59.71 \\
\hline & 44.53 & 20.74 & 18.26 & 139.24 & 59.77 \\
\hline & 66.15 & 19.67 & 17.19 & 143 & 59.55 \\
\hline & 87.35 & 17.34 & 14.86 & 154 & 59.88 \\
\hline & 108 & 16.55 & 14.06 & 154.3 & 60.04 \\
\hline
\end{tabular}




\section{CONCLUSION}

The study of the effect of benzoic acid derivatives on cupper electrodeposition led to the following important conclusions:

1. Rate of copper deposition decreases by adding organic compounds.

2. Rate of copper deposition depends on the type and concentration of the organic compound.

3. Rate of copper deposition increases by increasing temperature.

4. The copper electodeposition is diffusion controlled.

5. The discharge velocity of oxygen gas is affected by the presence of additive compounds to same extent as the mass transfer coefficient does.

\section{REFERENCES}

1. H. Voget, 1981. Electrochim. Acta, 263: 1311.

2. S. Sides and C. W. Tobias, 1982. J. Electrochem. Soc., 129, 2715.

3. C. W. Tobias, 1959. J. Electrochem. Soc., 106:833.

4. J. E. Funk and J. F. Thrope, 1972. J. Electrochem. Soc. 8:436.

5. P. A. Damma, 1974. J. Electrochem. Soc, 121:1286.

6. S. Mohanta and T. Z. 1977. Fahidy, J. Appl. Electrochem., 7:235.

7. V. A. Ettel., B. V. Tilak and A. S. Gendron, 1974. J. Electrochem. Soc., 121:867.

8. L. Sigtist et al, 1979. Int. J. Heat Mass Transfer, 22:1393.

9. M. G. Fouad, F. N. Zein and M. I. Ismail, 1971. Electrochimical Acta, 16:1477.
10. G. H. Sedahmed, S. S. Iskander, I. A. S. Mansour and M. A. Fawzy, 1980. Surface Technology, 11:67.

11. A. M. Ahmed and H. M. Faid-allah, 1987. J. Electrochem. 3:255.

12. E. Mattsson and J. O'M. Bockris, 1959. Trans. Faraday. Soc., 55:1586.

13. J. Lipkowski and P. N. Ross. 1992. Adsorption of Molecules at Metal Electrodes, VCH Publishers, New York, Weinheim, Cambridge.

14. F. Donnue and K. Nobe, 1965. J. Electrochem. Soc., 112:886.

15. G. Poling, 1976. J. Electrochem. Soc., 114:1209.

16. O. Ikeda, H. Jimbo and H. Jaumura, 1982. J. Electroanal. Chem., 137:127.

17. R. Parsons, 1964. J. Electroanal. Chem., 7:136.

18. J. O. M. Bockris and D. A. J. Swinkels, 1964. J. Electrochem. Soc., 111:736.

19. B. Ateya, B. E. El-Anadouli and F. M. El-Nizamy, 1984. Corros. Sci, 24:509.

20. E. E. Oguize, B. N. Okolue, C. E. Ogukwe, A. I. Onuchukwu and C. Unaegbu., 2004. Bull. Electrochem., 20:421.

21. E. E. Ebenso, U. J. Ekpe, B. I. Ita, O. E Offioong and U. J. Ibok, 1999. Mater. Chem. Phys., 60:79.

22. E. E. Ebenso, 2003. Bull. Electrochem., 19:209.

23. M. A. Quraishi, and R. Sardar, 2002 Bull. Electrochem., 18:515.

24. J.D. Talati and J. M. Darji, 1988. J. Ind. Chem. Soc., 65:94.

25. E. Yung and L. Romankiw, 1989. J. Electrochem. Soc., 136:756.

26. W. Plieth, 1992. Electrochim. Acta, 37:2115.

27. L. Bonou, M. Eyraud. R. Denoyel and Y. Massiani, 2002. Electrochim. Acta, 47:4139.

28. D. Stoychev and C. Tsvetanov, 1996. J. Appl. Electrochem., 26:741. 